the elevated, well-watered hills and low mountains, together with the east slope of the Rockies in South Dakota, Montana, and Wyoming.

2. The limitations of the supply.

It was estimated that about 69,600 million tons of water fall annually on the foot-hills within this drainage basin. Having limited the source to the foot-hills, it is clear that the limitations can be carried further. The water flowing through the Dakota sandstone must either $(\alpha)$ have fallen directly upon the area of outcrop, or $(b)$ have sunk into it from streams flowing over it, or (c) have escaped into it at high altitudes from other strata.

(a) It is estimated by Professor G. E. Culver ${ }^{1}$ that about $\frac{1}{72}$ of the rainfall of the Black Hills falls directly upon the outcropping Dakota sandstone. If this outcrop forms the same proportion of other foot-hills, then about 966 million tons per annum would fall directly upon this; and, as it is estimated that one-third of the rain-fall is absorbed by the soil, 322 million tons would be poured directly into the artesian basin.

(b) As far as the writer knows, but one stream has been care. fully studied as to the quantity of water lost to the stratum in question. Below Great Falls, Montana, the Missouri River flows across the outcropping Dakota sandstone at an altitude of 2.800 feet. Col, E. S. Nettleton ${ }^{2}$ made careful gaugings of the river before and after crossing the sandstone and found that it lost " 834 cubic feet per second," which would amount to 918 million tons per annum. The Yellowstone River, which is about as large

\section{A ROW OF HIEROGLYPHS, CASA NO. 2, PALENQUE.}

By H. T. Cresson, A.M., M.D., Philadelphia, Pa.

THERE is a perpendicular row of three glyphs just above the child-like figure, upheld in the arms of the Ahkin (?), on the centre slab of the so-called "Group of the Cross," Casa No. 2, (Stephens), Palenque, and two hieroglyphs in the parallel line to the right of the perpendicular line just mentioned, which are exceedingly interesting, and all of them, except the upper-centre component of the glyph, just above the child-like figure, are in a fair state of preserration. The upper centre component of this glyph (Fig. 6) has been badly injured, if we may judge by a photograph of the slab from Casa No. 2, taken by Dr. Manuel Urbino, the learned conservator of the Museo Nacional, at the City of Mexico It is a lucky circumstance that this masterpiece of the Maya scribe-sculptor's art has been cared for by the Mexican government, and it is to be hoped that they will protect other tablets at Palenque from the wanton destruction of the Mayas, who have been accused, by recent explorers, of chopping to pieces, with their machetes, the artistic productions of their ancestors.

It will be impossible, in this necessarily brief article, to consider the entire row of glyphs which have been indicated, we will, therefore, confine our remarks to that shown in Fig. 6 of the plate. If we compare this sketch, made from a photograph of the widdle slab of the cross group (Casa No. 2, Palenque), taken by Dr. Urbino, it will be seen that it differs in certain respects from the

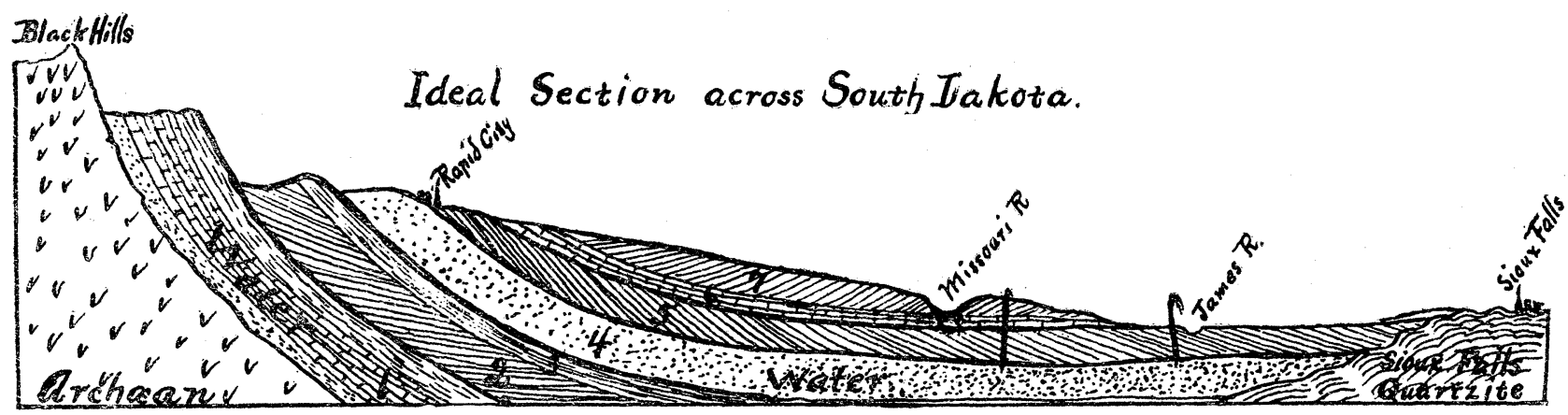

Length of Section, 385 miles. Rapid City to James River Valley, 230 miles.

1, Paleozoic_rocks, mostly water-bearing Carboniferous limestone; 2, Triassic shales, impervious; 3, Jurassic shales, impervious; 4, Cretaceous, Dakota sandstone, witer-boaring; 5, Cretace ous, Benton shales, impervious; 6, Cretaceous, Niobrara limestone; 7, Cretaceous, Pierre shales, impervious.

as the Missouri above their confluence, is said to flow across the Dakota sandstone and to lose a part of its volume. It is generally true that all streams flowing out of the foot-hills or away from the Rockies must, somewhere in their eastward course, cross the absorbing stratum. To estimate three times 918 million tons as the amount received from source $(b)$ will probably fall much within the limits. That gives us an aggregate from $(a)$ and $(b)$ of 3,076 million tons per annum.

(c) The outcrop of the Carboniferous forms a much larger part of the foot-hills area than does the Dakota. At least one-third of the water which falls directly upon it sinks, while nearly all of the small streams flowing out of the central Archæan area of the hills sink completely into the Carboniferous, only a few of the largest streams emerge from the thirsty Carboniferous area. The amount of water entering the Carboniferous strata is many times greater than that entering the Dakota. Now it is possible for nearly all of the water which it absorbs to escape into the Dakota, which it would do anywhere between its source and the James River valley if either one of two things were true: (1) If the overlying stratum "pinches out," or (2) if it is fractured or faulted. Both, one, or neither of these things may be true. No one has yet attempted to answer, conclusively, the question, " What becomes of the water which sinks into the Carboniferous limestone of the hills?" Until that question is answered, it will be impossible to determine the limitations of the water-supply of the artesian basin.

1 "Artesian and Underflow Investigation," Part III., p. 207.

2 "Artesian and Underfl w Investlgation," Part II., p. 77. drawing of Del Rio, Waldeck, Catherwood, and Charnay. Del Rio's rendition of this hieroglyph (Fig. 1) is absurdly incorrect, and has been suggested, we think, either by a slovenly impression of the centre bar of a cross (see Waldeck's Fig. 2), or else the artist drew upon his imagination and supplied the detail.

Waldeck's drawing (Fig. 2) in four of the small glyphs (composing the compound glyph) is not so far astray as one might expect, judging by the way his drawings have been condemned by sone writers, and I find that in the perpendicular and the parallel row of glyphs of the Casa No. 2 tablet, to the right of the symbol of the days, four winds, and cardinal points (called by many the Cross), his work compares quite as well with the photograph as that of Charnay, who used the camera, and Catherwood, who used the camera lucida. So far as I can learn, Mr. Waldeck used no artificial aids to assist him in his work (?); if this be the case, his eye must have been an unusually correct one, considering the amount of work he accomplished, and the contusing details that he encountered, to say nothing of annoyances in the way of flies, mosquitoes, garapatas, and other insects. I think the truth of this assertion will be apparent to anyone who has attempted to make a careful drawing under difficulties of this kind, especially such intricate details as we find in ancient Maya architecture and hieroglyphs, well calculated to give an experienced draftsman the beadache and heartache. The centre-upper component of the hieroglyph, drawn by Waldeck, differs from that of Fig. 6 , but I must not neglect to mention that the Urbino photograph indicates that this component of the glyph has been so injured that it is difficult, at present, to determine the details. The rcund incisions 
are apparent, as in Fig. 6. but they differ slightly in their position when compared with Catherwood (Fig. 3).

Stephens mentions that, at times, those engaged in commercial ventures have reached Santo Domingo del Palenque, and proceeded thence to the ancient Maya ruins, called, for want of a better name, Palenque, after the village near which they stand.

We have represented in Fig. 5 a sketch made by Mr. William Robert Thompson, who visited the ruins of Palenque in December, 1852, and again at a later date. Engaged in commercial pursuits in northern Chiapas and other parts of Mexico and Guatemala, Mr. Thompson has examined many of the old Maya cities, especially Qurigia and Palenque, sketching, in leisure moments, such details as he found interesting, preserving them for his own gratification. In looking over his portfolio some years ago I was struck with the resemblance of his drawing (Fig. 5) to that of Waldeck (Fig. 2). Mr. Thompson having returned to Mexico, I wrote to him in 1882 requesting a copy of his sketch, and, with all due courtesy, he presented me with the original, accompanying it with an autograph letter. The letter and sketch I shall forward to the American Philosophical Society of Philadelphia, so that they can be preserved for future examination.

Comparing the Thompson sketch with that of Mr. Waldeck, it will be seen that the latter has omitted the small incised circles which are present in the former, on the har of the cross and at its top and sides, which Mr. Thompson's letter especially mentions as present. Waldeck, in the cross-like glyph, to the right, gives
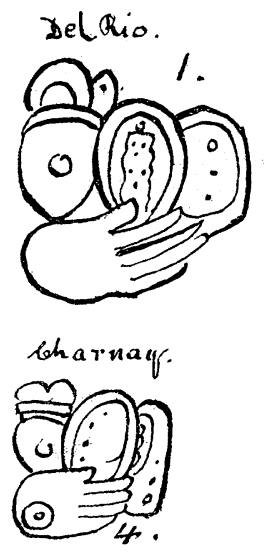
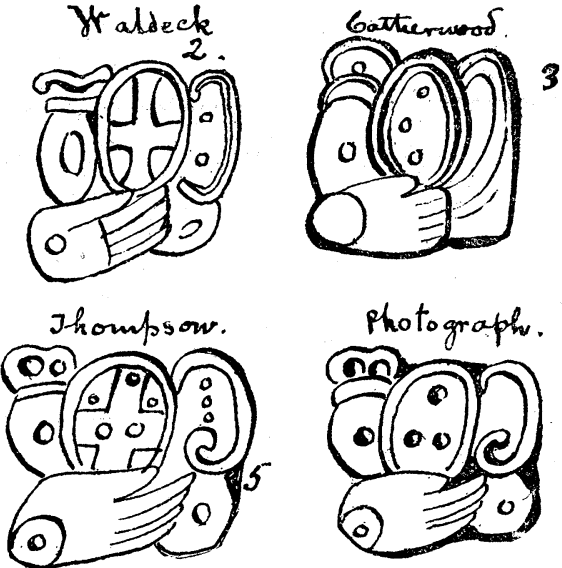
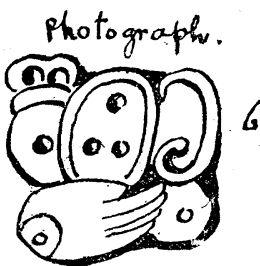

two small circles as its components, and Thompson gires three, which Charnay also indicates in Fig. 5, while both he and Catherwood omit the small round glyph with the incised circle, which is shown at the lower right-hand side in the Urbino photograph (Fig. 6), also in the sketches of Waldeck and Thompson. It is not surprising that so careful a draftsman as Catherwood should have omitted details in drawing this glyph, ill as he was with fever and subjected to annoyances which only those who bave encountered them can appreciate.

All of the drawings of this (Fig. 6) glyph differ more or less; those of Waldeck and Thompson hare four of the small glyphs represented with a fair degree of exactitude, accepting the photograph as our standard; Catherwood and Charnay have three details of the compound glyph which are, in a measure, correct. The fact that Messrs. Waldeck and Thompson both give a symbol resembling the symbol of the cardinal points as a component of the glyph which we are considering, suggests a probability that it existed and has been effaced. The surface of the glyph at present being so mutilated it would be best to examine the original tablet with care before deciding the matter, which I hope someone interested in palæography will have the opportunity of doing in the near future. The position of the three small circles in Fig. 6 correspond with the Thompson sketch (Fig. 5), even if the cross is absent, and, as Thompson gives an incised circle to either side of the cross at the top, it is not improbable that a series of dotted lines, or circles, at one time ran completely around the glyph, as we see a slight suggestion of this in Charnay's sketch (Fig. 4), and also in Catherwood's Fig. 3. Mr. Thompson asserts, positively, in his letter, that a cross did exist, and that the three incised circles were present on its perpendicular and parallel bars. He has, in a recent conversation upon the suhject, expressed the belief that this symbol of the winds has been mutilated intentionally, and that the two circles at the sides of the pe:pendicular bar are quite recent additions, made by someone trying to alter the glyph into the semblance of a face. Two small circles on either side suggest the eses, and the upper portion of the perpendicular upright above heing mutilated across, just beyond its point of junction with the parallel bar, thus produces a semblance to a nose, the parallel bar assuming somewhat the appearance of a mouth. This seems to be the case in the small Urbino photograph, but in the enlarged copy the mutilation of the glyph is more apparent, yet, as we have suggested, these matters can only be decided upon by a careful study of the original tablet.

A realistic drawing of the upper-centre component of this hieroglyph would be of great value for comparison with the photograph, as there are some details which the camera does not reproduce. If some of our artists visiting the Muséo Nacional, at the City of Mexico, would make a careful drawing of the Casa No. 2 tablet, it would be of great value to those engaged in the study of Maya palæography, and no doubt determine the question whether a cross and its dots (Fig. 5) are to be accepted as the true components of the glyph, or the details given in Fig. 6 of the plate accompanying this article. Until these doubts be settled, attempts at its interpretation are useless.

\section{THE OSAGE RIVER AND ITS MEANDERS.}

By arthur winslow, office of the geological surVey, JeFFerSON CITY, Mo.

In the remarks upon the Osage River in Miscouri, which form part of his admirable notice of the topographic maps of the U. S. Geological Survey, published in Science of April 28, 1893, Professor Davis has, with great acumen, hit upon one of the most noticeable features of the drainage of the State, or, at least, of the southern part. The peculiar meandering of the deeply trenched Osage Valley around spurs of high upland country, as referred to by us in a recent report of the Geological Survey, ${ }^{1}$ is a feature shared by nearly all of the principal streams of the Ozark region. The Meramec and the Gasconade Rivers, the Big Piney and the Bourbeuse Creeks of the northern slope hare the same swinging course; as have also their tributaries and those of the Osage itself. White River, on the southern slope, in Missouri and Arkansas, is characterized by similar convolutions. The courses of Big River and of the St. Francois River in the southeast have a like aspect. In strong contrast to this are the streams of that portion of the State lying north of the Missouri River-the drift-corered area. Here the courses are, in a general way, straight, of ten parallel in groups, the meanders of the streams confined to their present flood plains; their channels apparently having originated in the mantle of glacial drift. They are comparatively of recent origin, the older drainage system which lies masked beneath the drift may have been more tortuous.

The suggestive explanation which Professor Daris offers for the sunken curved course of the Osage, $i$ e., that it has been developed, through elevation and corrosion, from the flood-plain meanders of the stream, originating during an earlier base-leveled condition of the country, seems a natural explanation and is in many respects satisfactory. Still we hesitate to accept it in the present stage of our knowledge on mere a priori grounds. We see that it calls for a previous base-leveling of the whole Missouri-Ozark region, if not of the contiguous or even remoter Arkansas territory. Further, the hypothesis has so intimate a bearing upon the problems of recent geologic history of this country, ove $r$ and above its relation to the derelopment of the topography, that we wish to see full test made of its sufficiency before we adopt it as an axiom.

According to the best light we have at present, we recognize that the Ozark area was uplifted in late Cambrian times and remained above water level, in part at least, probably until the carboniferous period; that, if entirely submerged during the Mississippian epoch, it was so only long enough to receive but a

$$
1 \text { "Report on Iron Ores," vol. ii, p. } 89 .
$$

